\title{
COMPARISON OF ADAPTATION ASSESSMENT OF FOUR LOCAL SPRING WHEAT VARIETIES IN KABUL CLIMATIC CONDITIONS
}

\author{
Mohammad Hakim Osmani ${ }^{1}$ \\ ${ }^{1}$ Assistant Professor at Department of Agronomy, Agriculture Faculty of Kabul University, Jamal \\ mina Kartai-Sakhi \\ Tamim Fazily ${ }^{2}$ \\ 2 Assistant Professor at Department of Agronomy, Agriculture Faculty of Baghlan University, \\ Pulikumri-3601Afghanistan
Beheshtah Kohshani $^{3}$
${ }^{3}$ Assistant Professor at Department of Agronomy, Agriculture Faculty of Baghlan University, Pulikumri-3601Afghanistan \\ Mujtaba Mirzaee ${ }^{4}$ \\ ${ }^{4}$ MSc student at department of Agronomy, Faculty of Agriculture, Kabul University, \\ Afghanistan
}

Article DOI: https://doi.org/10.36713/epra3885

\begin{abstract}
A field experiment was conducted for two consecutive spring seasons of 2017 and 2018 at experimental farm of the Kabul University, to study effects of varieties on growth, yield components and yield of wheat under Agro-climate conditions of Kabul. The experimental was laid out in randomized complete block design with four treatment and three

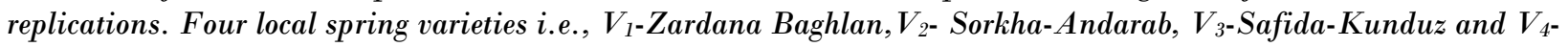
Safida-Andarab. Among the varieties Safida-Andarab $\left(V_{4}\right)$, produced shorter plant height but significantly higher number of tillers (416.67 and $425.33 \mathrm{~m} 2$ ), spikes (397.33 and 419.6), number of grains per spike (50.67 and 53.33), grains per spike length (3.00 and 3.00), test weight (40.33 and $41.33 \mathrm{~g}$ ) and grain yield of (4.17 and 4.43 t/ha) of wheat, being at par with variety of Safida-Kunduz during both the consecutive years, respectively.
\end{abstract}

KEY WORDS: local varieties, adaptation, climatic condition, yield, wheat 


\section{INTRODUCTION}

Afghanistan is a semi-arid country where where drought occurs frequently due to fluctuation in a rain-fed region. Wheat cultivation in Afghanistan depends either directly on precipitation or on irrigation (FAO/WFP, 2003). A large part of the wheat crop is grown in the Northern provinces with the majority of the crop being dependent on seasonal precipitation. The total wheat production in Afghanistan is $5.00 \mathrm{t} /$ ha which is achieved from an area of 2.30 million hectare with the annual productivity of 2.17 ton/ha (USDA and MAIL-Afghanistan, 2019).

Adaptation to drought stress is considered an important progress in the selection of wheat genotypes. However drought stress is found to be major constraint for crop production globally. It affect the growth and productivity of wheat by including many biochemical and molecular response of the crop under variable environmental condition Allahverdiyev et al. (2015). The ability of a cultivar to produce high and satisfactory yield over a wide range of stress and nonstress environments is very important. Finlay (1968) believed that stability over environments and yield potential are more or less independent from each other. The most widely used criteria for selecting high yield performance are mean yield, mean productivity (average yield performance under stress and non stress conditions) and relative yield performance in droughtstressed and more favorable environments Rashid et al. (2003). Bari (1990) found that the among eleven tested wheat genotypes, the wheat variety of Kanchann produced significantly higher grain yield. Chatterjee et al. (1980) carried out an experiment with three wheat cultivars (Janak, UP262 and Sonalika) and observed that significantly higher grain yield of wheat was obtained with Janak and lowest with Sonalika. Keeping all the above fact selection of resistant varieties with high adoptability to specific environmental condition is necessary to for higher grain yield.

\section{OBJECTIVE}

To assess the comparative performance of four local spring wheat varieties under Kabul climatic condition.

\section{METHODOLOGY}

A field experiment was conducted for two consecutive spring seasons of 2017 and 2018 at experimental farm of the Kabul University. The experiment was laid out in a randomized complete block design consisting of three replications and four treatments. The underground water level of site of the experiment was expected to be 10 to $11 \mathrm{~m}$ below the soil surface. The fertilizers were applied through Urea $200 \mathrm{~kg} / \mathrm{ha}$ and DAP $175 \mathrm{~kg} / \mathrm{ha}$ as basal. The crop was sown with the seed rate of $120 \mathrm{~kg} / \mathrm{ha}$ on March 10 under rainfed condition, only one supplemental irrigation was given on May 28 was during both the years. All the growth and yield parameters were measured as per standards at different observations taken during both the experimental years. The crop was harvested with the help of sickles, bundled separately, tagged properly and sundried. Later the crop was threshed, and grains were cleaned and weighted as per plot, separately during both the experimental years.

\section{RESULTS AND DISCUSSION}

The plant height of wheat was significantly influenced by different varieties during both the years. The significantly taller plant height of 88.4 and $86.8 \mathrm{~cm}$ were recorded with $\mathrm{V}_{1}$. Sorkha-Andarab during both the consecutive years, respectively, while during both the years the lowest plant height of wheat was observed with Safida-Andarab (table 1). There were observed significant difference among varieties. These findings are in agreement with Alam (2009). 
Table 1: Growth and yield parameters of different local varieties under Kabul climatic condition

\begin{tabular}{|l|c|c|c|c|c|c|c|c|}
\hline \multirow{2}{*}{ Treatments } & $\begin{array}{c}\text { Plant } \\
\text { height } \\
\text { (cm) }\end{array}$ & $\begin{array}{c}\text { Plant } \\
\text { height } \\
\mathbf{( c m )}\end{array}$ & $\begin{array}{c}\text { Tillers } \\
/ \mathbf{m}^{2}\end{array}$ & $\begin{array}{c}\text { Tillers } \\
/ \mathbf{m}^{2}\end{array}$ & $\begin{array}{c}\text { Spikes } \\
/ \mathbf{m}^{2}\end{array}$ & $\begin{array}{c}\text { Spikes } \\
/ \mathbf{m}^{2}\end{array}$ & $\begin{array}{c}\text { Spike } \\
\text { length } \\
\text { (cm) }\end{array}$ & $\begin{array}{c}\text { Spike } \\
\text { length } \\
\text { (cm) }\end{array}$ \\
\cline { 2 - 9 } & $\mathbf{2 0 1 7}$ & $\mathbf{2 0 1 8}$ & $\mathbf{2 0 1 7}$ & $\mathbf{2 0 1 8}$ & $\mathbf{2 0 1 7}$ & $\mathbf{2 0 1 8}$ & $\mathbf{2 0 1 7}$ & $\mathbf{2 0 1 8}$ \\
\hline V $_{1}$. Zardana-Baghlan & 80.00 & 78.83 & 271.33 & 296.00 & 246.00 & 275.67 & 8.17 & 9.83 \\
\hline V $_{2}$ Sorkha-Andarab & 88.40 & 96.83 & 365.67 & 358.33 & 342.67 & 350.33 & 9.00 & 8.50 \\
\hline V $_{3}$ Safida- Kunduz & 71.50 & 77.67 & 370.00 & 385.33 & 378.00 & 373.67 & 9.45 & 10.50 \\
\hline V $_{4}$ Safida- Andarab & 68.67 & 75.50 & 416.67 & 425.33 & 397.33 & 419.67 & 10.67 & 10.83 \\
\hline SEM & $\mathbf{2 . 3 4}$ & $\mathbf{1 . 4 4}$ & $\mathbf{1 4 . 8 0}$ & $\mathbf{1 7 . 7 8}$ & $\mathbf{1 4 . 9 3}$ & $\mathbf{1 7 . 5 1}$ & $\mathbf{0 . 4 4}$ & $\mathbf{1 . 0 5}$ \\
\hline CD & $\mathbf{8 . 2 7}$ & $\mathbf{5 . 0 8}$ & $\mathbf{5 2 . 2 2}$ & $\mathbf{6 2 . 7 3}$ & $\mathbf{5 2 . 6 6}$ & $\mathbf{6 1 . 7 6}$ & $\mathbf{N S}$ & $\mathbf{N S}$ \\
\hline
\end{tabular}

The significant increase in yield attributes of wheat was recorded with Safida-Andarab $\left(\mathrm{V}_{4}\right)$, which produced significantly higher number of tillers (416.67 and $425.33 \mathrm{~m} 2$ ), spikes (397.33 and 419.6), number of grains per spike (50.67 and 53.33), grains per spike length (3.00 and 3.00) and test weight (40.33 and 41.33 g) of wheat, being at par with variety of Safida-Kunduz during both the consecutive years, respectively (table 2 ). The higher yield attributes of wheat is due to higher drought resistant and environmental adoptability of $\mathrm{V}_{4}$ under varying climatic situation. These findings are in line with Alam (2009). Kabir (2009) also found significant variation in yield attributes of wheat with different local varieties. Bari (2003) observed significant differences in test weight of wheat among different wheat varieties sown spring season.

The significantly higher grain yield of 4.17 and $4.43 \mathrm{t} /$ ha of wheat was produced by Safida-Andarab followed by Safida-Kuduz during both the consecutive years, respectively. The significantly higher grain yield of wheat with mentioned treatments are due to higher yield attributing character of wheat which theses characters contributed to the final yield of wheat. Similar result was also observed by Kabir (2009) and Alam (2009).

Table 1: Yields attributes and yield of different local varieties under Kabul climatic condition

\begin{tabular}{|c|c|c|c|c|c|c|c|c|c|c|}
\hline Treatments & $\begin{array}{c}\text { Spikelets/ } \\
\text { spike }\end{array}$ & $\begin{array}{c}\text { Spikelets/ } \\
\text { spike }\end{array}$ & $\begin{array}{l}\text { Grains/ } \\
\text { spike }\end{array}$ & $\begin{array}{l}\text { Grains/ } \\
\text { spike }\end{array}$ & \begin{tabular}{|l} 
Grains \\
/spikelet
\end{tabular} & \begin{tabular}{|l|} 
Grains \\
/spikelet
\end{tabular} & $\begin{array}{c}\text { Test } \\
\text { weight } \\
\text { (g) }\end{array}$ & $\begin{array}{c}\text { Test } \\
\text { weight } \\
\text { (g) }\end{array}$ & $\begin{array}{c}\text { Grain } \\
\text { yield } \\
\text { t/ha }\end{array}$ & $\begin{array}{c}\text { Grain } \\
\text { yield } \\
\text { t/ha }\end{array}$ \\
\hline & 2017 & 2018 & 2017 & 2018 & 2017 & 2018 & 2017 & 2018 & 2017 & 2018 \\
\hline $\begin{array}{l}\text { V } 1 \text {. Zardana- } \\
\text { Baghlan }\end{array}$ & 12.67 & 11.33 & 31.67 & 35.33 & 2.00 & 2.67 & 33.00 & 31.50 & 2.87 & 3.20 \\
\hline $\begin{array}{l}\text { V }{ }_{2} \text { Sorkha- } \\
\text { Andarab }\end{array}$ & 13.67 & 13.00 & 39.43 & 40.00 & 2.33 & 2.83 & 35.00 & 33.83 & 3.30 & 3.30 \\
\hline $\begin{array}{l}\text { V3. Safida- } \\
\text { Kunduz }\end{array}$ & 13.67 & 13.67 & 45.67 & 46.33 & 2.67 & 3.00 & 37.00 & 38.00 & 3.67 & 4.07 \\
\hline $\begin{array}{l}\text { V4. Safida- } \\
\text { Andarab }\end{array}$ & 14.00 & 14.67 & 50.67 & 53.33 & 3.00 & 3.00 & 40.33 & 41.33 & 4.17 & 4.43 \\
\hline SEM & 0.44 & 0.57 & 1.89 & 2.80 & 0.20 & 0.20 & 1.32 & 1.29 & 0.15 & 0.16 \\
\hline $\mathrm{CD}$ & NS & NS & 6.68 & 9.89 & NS & NS & 4.67 & 4.54 & 0.54 & 0.57 \\
\hline
\end{tabular}

\section{CONCLUSION}

Among the varieties Safida-Andarab $\left(\mathrm{V}_{4}\right)$, produced produced shorter plant height but significantly higher number of tillers (416.67 and $425.33 \mathrm{~m} 2$ ), spikes (397.33 and 419.6), number of grains per spike (50.67 and 53.33), grains per spike length (3.00 and 3.00), test weight (40.33 and $41.33 \mathrm{~g}$ ) and grain yield of (4.17 and $4.43 \mathrm{t} / \mathrm{ha}$ ) of wheat, being at par with variety of SafidaKunduz during both the consecutive years, respectively.

\section{Recommendations}

To achieve maximum yield of wheat from these spring varieties ( $\mathrm{V}_{1}$-Zardana Baghlan, $\mathrm{V}_{2}$ - Sorkha-Andarab, $\mathrm{V}_{3}$-Safida-Kunduz and $\mathrm{V}_{4^{-}}$Safida-Andarab) under climatic condition of Kabul, Safida-Andarab may be recommended for farmers . 


\section{REFERENCES}

1. Allahverdiyev, T. I., Talai, J. M., Huseynova, I. M., \& Aliyev, J. A. (2015). Effect of drought stress on some physiological parameters, yield, yield components of durum (Triticum durum desf.) and bread (Triticum aestivum L.) wheat genotypes. Ekin Journal of Crop Breeding and Genetics, 1(1), 50-62.

2. Alam, A. K. M. K. (2009). Effect of irrigation and variety on the growth and yield of wheat. (M.Sc thesis. Department of Agronomy. Bangladesh Agricultural University, Mymensingh).

3. Bari (2003) Annual Report. 2002-2003. Wheat Res. Centre, Bangladesh Agril. Res.Inst. Joydebpure, Gazipur. p. 31.

4. Bari (1990). Means of wheat production by profitable method (A booklet in Bangla). Wheat Research Centre, Bangladesh Agril. Res. Inst. Nashipur, Dinajpur. pp. 5-6

5. Chatterjee, B.N.; Chatterjee, M. and Das, N.R. (1980). Note on differences inthe response of wheat varieties to boron. Indian J. Agric. Sci. 50(10): 796.
6. FAO/WFP.2003. Special Report-FAO/WFP CFSAM to Afghanistan.

7. Finlay, K. W., G. N. Wilkinson (1963). The Analysis of Adaptation in a Plant-Breeding Programme. Aust. J. Agric. Res. 14:742-754.

8. Kabir, M. M. 2009. Effect of variety and weed management on the yieldand yield component wheat. (MSc Thesis. Department of Agronomy. Bangladesh Agricultural University, Mymensingh).

9. Rashid, A, Q. Saleem, A. Nazir and H. S. Kazım (2003). Yield potential and stability of nine wheat varieties under water stress conditions. International Journal of Agriculture and Biology 5(1):7-9.

10. United States Department of Agriculture (USDA). (2019) Foreign agricultural serviceloffice of global analysis international production assessment division (IPAD), Ag Box 1051, Room 4630 South Building, Washington DC 20250-1051, https://ipad.fas.usda.gov.Cv

11. USDA, 2002. Afghanistan: Limited improvement in Spring Harvested Grain. 